\title{
ANALISIS INDEKS KINERJA USAHA KECIL MENENGAH DI KOTA BOGOR
}

\author{
Analysis of Small and Medium Enterprises Performance Index in Bogor City
}

Faisal Ramdhani*, Hartrisari Hardjomidjojo*

\author{
Departemen Teknologi Industri Pertanian, Fateta IPB, Kampus IPB Darmaga PO Box 220 Bogor 16002, \\ Telpon/Fax : 0251-8621974
}

Diterima 02 Februari 2019 / Disetujui 11 Februari 2019

\begin{abstract}
Small and Medium Enterprises (SMEs) is the locomotive of economic development of Indonesia. Within the framework of the national economy, SMEs have contributed to the recruitment of labor, the increase of Gross Domestic Product (GDP) as well as the increase of export value and national investment. In the vision and mission of Bogor city government, SMEs are expected to become the economic buffer of the city of Bogor in the face of free market competition. Currently there are 13.953 SMEs in the city of Bogor. Sustainability Index based on multi dimensional scaling can be used to measure the performance status of SMEs and formulate specific strategies that need to be done to improve their competitiveness. This research was conducted from dimension setting, attribute determination, attribute review, multidimentional scaling analysis, Monte Carlo and Leverage. The value of Stress and $R 2$ resulted is less than 0.25 and more than 0.80 so that the data has good of fit. The Monte Carlo analysis results for all SMEs have been valid because it has sustainability index ratio with Monte Carlo index less than 5\%. The results show that the average sustainability index for SMEs in Bogor city is 49.8, which means that the city of Bogor is in sufficient condition (index value is below 50). The result also shows that ecological and economical factors are the important factors for increasing the performance of SMEs. The simulation results show that changes in related dimensions can increase the average value of the sustainability index to above 60 (good category).

Key Words : Small and Medium Enterprises (SMEs), Sustainability Index, competitiveness, multi dimensional scaling.
\end{abstract}

\begin{abstract}
ABSTRAK
Usaha Kecil Menengah (UKM) merupakan lokomotif pembangunan ekonomi Indonesia. Dalam kerangka ekonomi nasional, UKM sudah menyumbang dalam perekrutan tenaga kerja, peningkatan Produk Domestik Bruto (PDB) serta pertambahan nilai ekspor dan investasi nasional. Dalam visi dan Misi pemerintah kota Bogor, UKM diharapkan dapat menjadi penyangga ekonomi kota Bogor dalam menghadapi persaingan pasar bebas. Saat ini tercatat sejumlah 13.953 UKM di kota Bogor. Indeks keberlanjutan berdasarkan multi dimensional scaling dapat digunakan untuk mengukur status kinerja UKM dan merumuskan strategi yang perlu dilakukan untuk meningkatkan daya saingnya. Penelitian ini dilakukan mulai dari penenetuan dimensi, penentuan atribut, peninjauan ulang atribut, analisis multidimentional scaling, Monte Carlo dan Leverage. Nilai Stress dan R2 yang dihasilkan adalah
\end{abstract}

*Korespondensi Penulis:

Email : faisalramdh34@gmail.com; sari_rce@yahoo.com 
kurang dari 0.25 dan lebih dari 0.80 sehingga data telah good of fit. Hasil analisis Monte Carlo untuk semua UKM telah valid karena memiliki rasio sustainability index dengan indeks Monte Carlo kurang dari 5\%. Hasil penelitian menunjukkan bahwa indeks keberlanjutan rata-rata untuk UKM di kota Bogor adalah sebesar 49.8 yang berarti UKM kota Bogor berada dalam kondisi cukup berkembang (nilai indeks di bawah 50). Hal yang perlu mendapat perhatian dalam peningkatan daya saing adalah faktor ekologi dan ekonomi. Hasil simulasi menunjukkan bahwa perubahan pada dimensi terkait dapat meningkatkan nilai rata-rata indeks keberlanjutan menjadi di atas 60 (kategori baik).

Kata Kunci : Usaha Kecil Menengah (UKM), Indeks Keberlanjutan, Daya saing, multi dimensional scaling

\section{PENDAHULUAN}

Menurut Brahmasari dan Suprayetno (2008), kinerja merupakan pencapaian seseorang atau industri terhadap tujuan yang telah ditetapkan. Analisis kinerja dilakukan untuk mengetahui dan memahami hasil yang telah dicapai serta membuat keputusan yang tepat di waktu yang tepat sehingga dapat mencapai kesuksesan (EIS 2016). Analisis kinerja tidak hanya diperlukan bagi industri besar, namun juga industri kecil seperti Usaha Kecil Menengah (UKM). Usaha Kecil Menengah (UKM) didefinisikan sebagai usaha ekonomi produktif yang dimiliki oleh perorangan atau badan usaha yang bukan merupakan anak atau cabang perusahaan besar (DPR RI 2008). UKM berkontribusi terhadap pencitaan nilai tambah nasional sebesar Rp 5.440 triliun atau sebesar 60,34 $\%$ dari PDB nasional, dan juga memberikan kontribusi besar terhadap lebih dari 50\% dari total serapan tenaga kerja nasional (Rafinaldy 2004). UKM memiliki posisi strategis dalam meningkatkan taraf hidup masyarakat, yang dapat menjadi wadah hidup bersama antara produsen dan konsumen (Fitanto 2009).

Sebagai salah satu kota yang sebagian besar perekonomianya ditopang oleh UKM, Bogor menjadi salah satu kota yang perlu melakukan peningkatan terhadap kinerja UKM. Selama 2017, UKM menyumbang 70 persen dari seluruh pendapatan asli daerah Kota Bogor (Kompas 2018). Menurut KUMKM Kota Bogor (2016), jumlah UKM yang ada di Kota Bogor sebanyak 13.953 dan sebagian besar memiliki kapasitas yang rendah. Pada umumnya, pelaksanaan perbaikan kinerja terdiri dari lima tahap yaitu tahap analisis, tahap desain, tahap pengembangan, tahap implementasi, dan tahap evaluasi. Dari kelima tahapan tersebut, tahap analisis merupakan tahap yang penting karena untuk menentukan nilai kinerja yang diinginkan, sehingga dapat diketahui apakah tindakan perbaikan mempengaruhi perubahan kinerja atau tidak (Radnor dan Barnes 2007).

Analisis kinerja UKM di kota Bogor dilakukan menggunakan indeks keberlanjutan. Indeks keberlanjutan merupakan nilai yang menunjukan status keberlanjutan suatu industri. Analisis keberlanjutan UKM di kota Bogor ini dilakukan dengan pendekatan RAPKMBO (Rapid Appraisal for UKM Kota Bogor) yang merupakan pengembangan metode RAPFISH (Rapid Appraisal for Fisheries) yang digunakan untuk menilai status keberlanjutan perikanan tangkap (Suyitman et al. 2009). RAPFISH dikembangkan oleh Universitas Kolombia pada tahun 1999 (Fitrianti et al. 2014). Teknik ini dapat digunakan untuk industri kecil, menengah, maupun industri besar (Pitcher \& Preikshot 2001). Dengan menggunakan RAPFISH ini akan diperoleh gambaran yang jelas dan komprehensif mengenai kondisi di daerah penelitian, sehingga akhirnya dapat dijadikan bahan untuk menentukan kebijakan yang tepat untuk mencapai pembangunan yang berkelanjutan (Tahir et al. 2002). Pada Teknik ini digunakan metode multidimentional scaling untuk menunjukkan 
hubungan atribut setiap dimensi serta menilai secara cepat indeks dan status keberlanjutan sumberdaya yang dianalisis (Hartono et al. 2005). Evaluasi dilakukan pada tiga dimensi, yakni ekologi, sosial, dan ekonomi yang biasa digunakan dalam evaluasi keberlanjutan perikanan pada penelitian Pitcher et al. (2013).

Usaha kecil dan menengah di Kota Bogor penting untuk dikaji dan dikembangkan karena peran krusial dalam pertumbuhan ekonomi, serta memiliki kontribusi tinggi pada penyerapan tenaga kerja (Tambunan 2005). Dalam kerangka pengembangan ini, sangat penting memperhatikan skala usaha kecil menengah (UKM) pada sektor agroindusri (Junaidi et al. 2014). Tingginya potensi yang dimiliki oleh UKM, masih banyak memiliki kendala dalam perkembanganya. Kendala yang umumnya dihadapi yaitu manajemen yang belum profesional, keterbatasan teknologi, jangkauan pasar, jaringan kerja, akses lokasi yang strategis, permodalan, kualitas sumber daya manusia, sarana prasarana, dan informasi (Rifa'i 2013). Di samping itu, UKM kota Bogor menghadapi pula faktorfaktor yang masih menjadi kendala dalam peningkatan daya saing dan kinerja UKM. Faktor-faktor termaksud antara lain terbatasnya terhadap akses permodalan, akses ke pasar, dan terbatasnya akses informasi mengenai sumberdaya dan teknologi (Susilo 2007). Kendala-kendala tersebut mengakibatkan terhambatnya perkembangan UKM, sehingga kinerjanya rendah.

Analisis indeks kinerja terhadap UKM di Kota Bogor dilakukan untuk mengetahui secara umum kondisi faktual pengelolaan UKM di daerah tersebut. Analisis ini akan memberikan gambaran secara umum mengenai kondisi keberlanjutan UKM di Kota Bogor. Hasil analisis ini diharapkan dapat menjadi salah satu pertimbangan bagi pengambilan keputusan dan penentuan prioritas kebijakan pengelolaan UKM di Kota
Bogor dalam upaya peningkatan daya saing.

\section{Tujuan Penelitian}

Penelitian ini bertujuan untuk mengukur kinerja berdasarkan indeks keberlanjutan pada UKM pangan, non pangan, dan kerajinan kota Bogor menggunakan metode multidimensional scaling. Pengukuran dilakukan berdasarkan penilaian terhadap tiga dimensi yang terdiri dari ekologi, sosial dan ekonomi.

\section{Manfaat Penelitian}

Manfaat penelitian ini bagi UKM pangan, non pangan, dan kerajinan di Bogor adalah mendapatkan indeks keberlanjutan yang menggambarkan kondisi kinerja UKM serta rekomendasi manajemen sebagai acuan perbaikan kinerja UKM. Bagi peneliti, penelitian ini menambah wawasan mengenai UKM pangan dan non pangan, dan kerajinan di kota Bogor. Bagi pemerintah, khususnya Kementrian Koperasi dan UKM, hasil analisis dapat digunakan sebagai sarana evaluasi dan perbaikan strategi pengembangan UKM di untuk masa mendatang.

\section{Ruang Lingkup Penelitian}

Ruang lingkup penelitian ini adalah menganalisis indeks keberlanjutan UKM agroindustri di Kota Bogor berdasarkan tiga dimensi yakni ekologi, sosial, dan ekonomi. Indeks keberlanjutan merupakan nilai yang menunjukan status keberlanjutan suatu industri, dalam hal ini dihitung menggunakan teknik RAPKMBO (Rapid Appraisal for UKM Kota Bogor). Teknik RAPKMBO merupakan modifikasi dari RAPFISH untuk menghitung nilai indeks keberlanjutan UKM Agroindustri. Fokus UKM agroindustri dalam penelitian ini adalah 40 UKM agroindustri di Kota Bogor yang terpilih berdasarkan hasil sensus UKM di Kota Bogor, dan dikelompokan atas 18 UKM pangan, 10 UKM nonpangan, dan $12 \mathrm{UKM}$ 
Kerajinan. Dimensi dan indikator yang terpilih dalam pengukuran indeks kinerja dalam penelitian ini merupakan hasil studi literatur yang telah ditinjau ulang oleh pakar. Pembahasan kinerja difokuskan pada hasil pengukuran indeks kinerja yang digunakan untuk menggambarkan indeks keberlanjutan dan strategi yang perlu dilakukan untuk meningkatkan daya saing UKM di kota Bogor.

\section{METODOLOGI}

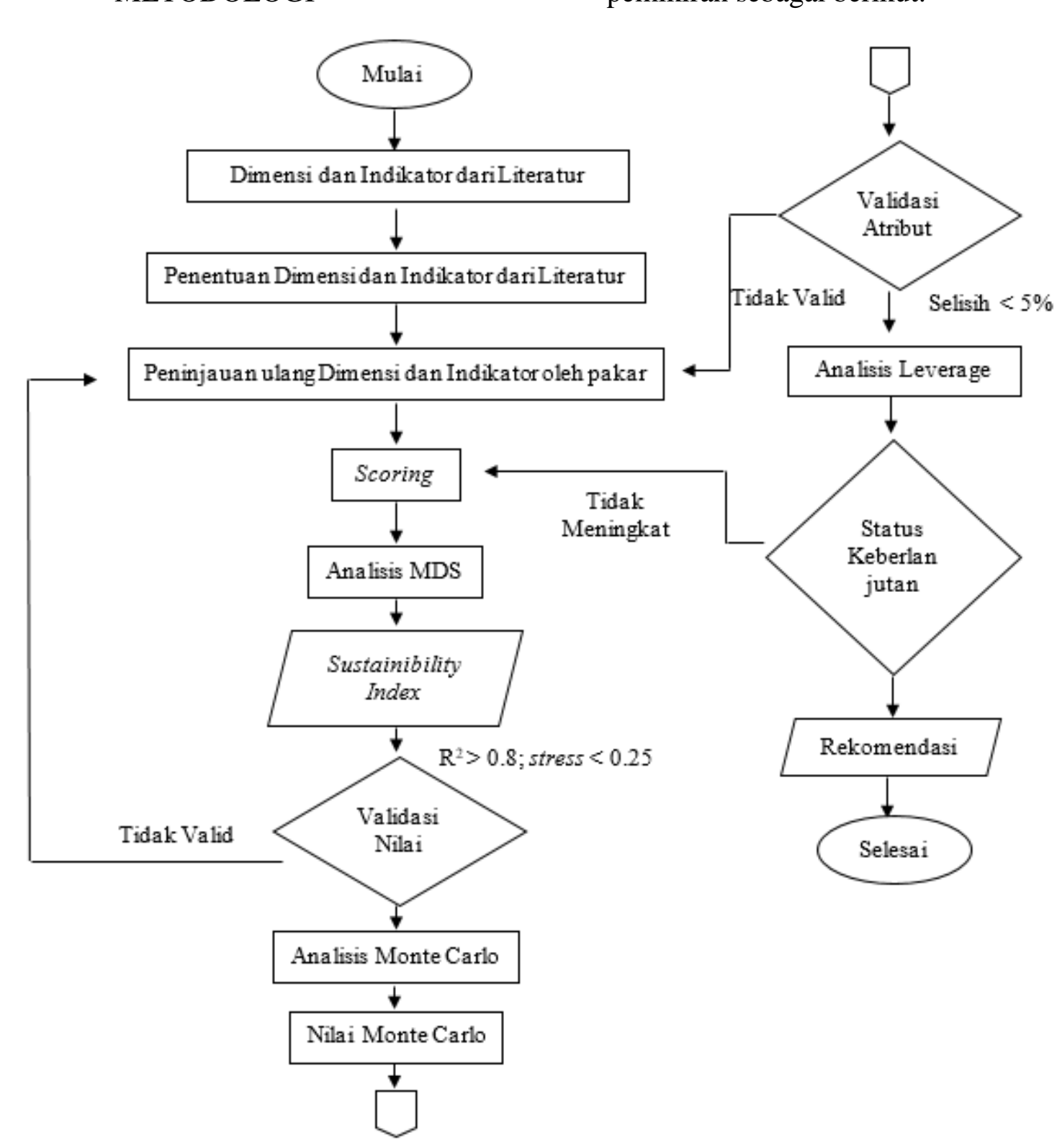

Gambar 1Kerangka Pemikiran analisis kinerja UKM kota Bogor

\section{Tempat dan Waktu Penelitian}

Penelitian ini dilakukan di kota Bogor, pada selang waktu Februari 2018 hingga Maret 2018.

\section{Metode}

Metode penelitian berfungsi menjelaskan prosedur yang digunakan untuk mencapai tujuan. Adapun metode yang digunakan dapat ilihat pada kerangka pemikiran sebagai berikut. 


\section{Penentuan Atribut dan Indikator}

Pada tahapan ini dilakukan studi literatur terhadap dimesi yang digunakan. Atribut yang sebelumnnya telah tersedia pada data UKM agroindustri di Kota Bogor dalam penelitian Hartrisari et al (2015), dikelompokan kedalam masing-masing dimensi dengan menyesuaikan pengertian tiap dimensi dan atribut berdasarkan literatur. Dalam setiap atribut terdapat indikator GOOD, BAD, atau yang berada diantara GOOD dan BAD yang di tuangkan sebagai skala ordinal. Dibawah ini merupakan literatur yang digunakkan sebagai acuan pengelompokan atribut, kedalam dimensi terpilih.

\section{Peninjauan Ulang Atribut dan Indikator Oleh Pakar}

Dimensi, atribut dan indikator dari hasil studi literatur, kemudian dilakukan peninjauan ulang oleh pakar sebelum masuk dalam langkah penilaian (Scoring). Peninjauan ulang bertujuan untuk melihat kesesuaian tiap dimensi, atribut, dan skala indikator yang digunakan dengan kondisi UKM, khususnya UKM yang ada di kota Bogor. Pakar yang meninjau ulang dimensi, atribut, dan skala indikator dalam penelitian ini adalah pakar yang dianggap memiliki pengalaman dan kompetensi di bidang industri, khususnya UMKM.

\section{Scoring}

Pemberian skor terhadap atribut dan indikator yang telah di evaluasi oleh pakar dilakukan menggunakan skala ordinal. Skor didapatkan dengan menyesuaikan data yang ada, dengan nilai indikator yang digunakan. Hasil scoring kemudian dianalaisis dengan multidimensional scaling, Monte Carlo, dan Leverage menggunakan RAPKMBO yang merukapan modifikasi RAPFISH pada Microsft Excel 2010.

\section{Analisis Multidimensional Scaling}

Data ordinal hasil scoring kemudian diolah menggunakan RAPKMBO yang merupakan hasil modifikasi dari RAPFISH, dengan memasukan informasi lokasi skor pada layout RAPFISH pada Microsoft Excel 2010. Pada analisis ini, melalui teknik ordinasi (penentuan jarak) bad $(0 \%)$ dan good (100\%) dapat diketahui posisi indeks keberlanjutan (sustainability index) terhadap anchor (Fauzi dan Anna 2002). Hasil analisis ini kemudian akan menghasilkan nilai yang kemudian disebit sebagai nilai sustainability index, dalam rentang 0-100. Selanjutnya nilai tersebut akan dikategorikan ke dalam beberapa kategori seperti pada table berikut.

Tabel 1 Kategori status sustainability index

\begin{tabular}{cc}
\hline Nilai Indeks & Kategori \\
\hline$<25,00$ & Buruk \\
\hline $25,00-49,99$ & Cukup \\
\hline $50,00-74,99$ & Baik \\
\hline$>75,00$ & Sangat Baik \\
\hline Kavanagh dan Pitcher (2004) \\
\end{tabular}
keberlanjutanya dikatakan buruk apabila berada pada rentang 0-25 (\%), cukup pada rentang 25-49,99 (\%), baik pada rentang 50$74,99(\%)$, dan sangat baik pada rentang diatas $75,00(\%)$. Untuk melakukan validasi keakuratan hasil analisis indeks keberlanjutan, digunakan nilai stress dan R2. Kategori nilai stress dapat dilihat pada tabel berikut :

Tabel 2 Kategori Nilai Stress

\begin{tabular}{cc}
\hline Stress & Good offit \\
\hline$>0.2$ & Random \\
$<0.15$ & Baik \\
$<0.1$ & Ideal \\
\hline
\end{tabular}

Clarke (1993)

Pada tabel diatas, nilai stress $<0.1$ di kategorikan sebagai kondisi paling ideal untuk menggambarkan keadaan UKM di kota Bogor. Sedangkan nilai stress $>0.2$ dikategorikan sebagai nilai random yang kurang bias menggambarkan keadaan yang sesuai UKM di kota Bogor. Batas toleransi 
dari nilai random adalah 0.25 (Fauzi dan Anna 2002).

Selain nilai stress, untuk melakukan validasi juga digunakan nilai R2 untuk mengetahui perlu tidaknya dilakukan penambahan atribut. Nilai R2 dikatakan baik apabila memiliki nilai $>0.8$ yang berarti atribut yang digunakan sudah sesuai, dan jika memiliki nilai < 0.8 maka diperlukan perubahan atribut yang digunakan (Hidayanto et al 2009).

\section{Analisis Monte Carlo}

Analisi Monte Carlo bertujuan untuk mengetahui dampak dari kesalahan acak pada selang kepercayaan 95\% dalam sebuah metode simulasi (Fauzi dan Anna 2002). Analisis ini digunakan untuk validasi atribut yang digunakan dalam pengukuran indeks keberlanjutan. Analisis Monte Carlo digunakan untuk memastikan tidak terdapatnya error dari pengukuran nilai sustainability index, dengan melihat selisih antara indeks Monte Carlo dan indeks keberlanjutan untuk mencari selisih terkecil (Hidayanto et al 2009).

\section{Analisis Leverage}

Pada analisis ini akan diketahui atribut yang paling sensitive yang berpengaruh paling besar dalam peningkatan nilai sustainability index secara signifikan dari suatu dimensi (Kavanagh dan Pitcher 2004). Hasil analisis akan ditampilkan dalam bentuk grafik batang, yang akan ditunjukan oleh nilai root mean square. Nilai root mean square yang semakin besar akan menunjukan dominasi sensitivitas atribut terhadap peningkatan nilai sustainabiliti index . Nilai yang dipilih adalah nilai yang lebih besar dibandingkan nilai tengahnya.

\section{HASIL DAN PEMBAHASAN}

$\begin{aligned} & \text { Penentuan Dimensi, } \\ & \text { Indikator } \\ & \text { Pengukuran indeks }\end{aligned}$
$\quad$ keberlanjutan

didasarkan atas 8 elemen pokok industri, yang termuat dalam bentuk dimensi dan atribut dengan tujuan untuk meningkatkan performa sistem produksi (Rostamzadeh dan Sofian 2009). Adapun 8 elemen pokok tersebut terdiri dari man, money, meachine, material, market, method, management, dan environtment. Delapan elemen pokok ini dipilih karena mewakili sumberdaya yang dimiliki UKM dalam mencapai tujuanya. Pada penelitianya, Pitcher et al (2013) melakukan evaluasi indeks keberlanjutan perikanana kedalam 5 dimensi pokok yakni, ekologi, sosial, ekonomi, teknologi, dan etis. Pada penelitian ini dipilih 3 dimensi yang menjadi dasar pengukuran indeks keberlanjutan yang antara lain adalah dimensi ekologi, sosial, dan ekonomi. Pada penelitian ini juga digunakan 13 atribut yang sebelumnnya telah tersedia pada data UKM agroindustri di Kota Bogor dalam penelitian Hartrisari et al (2015), yang menjadi data dalam membandingkan indeks keberlanjutan UKM satu dengan lainya di Kota Bogor. Kemudian atribut tersebut dikelompokkan kedalam 3 dimensi yang sebelumnnya telah dipilih. Pengelompokkan dilakukan dengan menyesuaikan pengertian tiap dimensi dan atribut berdasarkan literatur. Dimensi ekologi memiliki tiga atribut, yakni jumlah tenaga kerja, kapasitas produksi, dan teknologi. Terdapat empat atribut pada dimensi sosial, yakni pemasok, ketersediaan bahan baku, hasil limbah, dan jenis limbah. Dimensi ekonomi memiliki enam atribut, yakni biaya perawatan, organisasi, asal modal, omset/tahun, ekspor, dan wilayah pemasaran.

\section{Proses Peninjauan Ulang Oleh Pakar}

Peninjauan ulang atribut dan indikator oleh pakar bertujuan untuk melihat kesesuaian tiap dimensi, atribut, dan skala indikator yang digunakan dengan kondisi UKM, khususnya UKM yang ada di kota Bogor. Pada proses ini juga dilakukan untuk 
mengetahui apakah diperlukan penambahan atau pengurangan atribut dan indikator dari masing-masing dimensi. Pakar yang menjadi responden pada tahap penelitian ini adalah Bapak Dr. Cahyo Muhandri selaku staff dosen Ilmu dan Teknologi Pangan IPB, Bapak Prof. Dr.Ir. H. Musa Hubeis, MS, Dipl.Ing, DEA selaku Guru Besar Manajemen Industri IPB, dan Bapak Dr.Ir.H. Meika Syahbana Rusli, M.Sc selaku Konsultan Dinas Perindustrian RI (2006) dan Direktur Bogor Life Science and Technology. Pada proses ini tidak terjadi adannya penambahan atau pengurangan dimensi dan atribut hasil studi literatur, namun terjadi beberapa perbaikan skala indikator yang dianggap kurang sesuai. Hasil peninjauan oleh pakar menekankan pada perbaikan dan penggunaan kata yang lebih tepat pada atribut dan indikator yang digunakan. Serta lebih merincikan dan menghilangkan indikator yang dirasa tidak perlu untuk digunakan.

\section{Scoring}

Tahapan selanjutnya setelah atribut dan indikator ditinjau oleh pakar, maka dilakukan proses scoring data kedalam skala ordinal.
Data yang tersedia pada data UMKM kota Bogor, kemudian disesuaikan dengan skala ordinal pada indikator tiap atribut dan dimensi sehingga di dapatkan skor dalam bentuk angka ordinal. Hasil scoring tersebut, kemudian akan di gunakana sebagai data untuk melakukan analisis indeks keberlanjutan, Monte Carlo, dan Leverage.

\section{Analisis Multidimensional Scaling}

Analisis Multidimensional Scaling untuk mengukur nilai sustainiability index ini, dilakukan terhadap 40 UKM agroindustri di Kota Bogor yang dibagi kedalam tiga kelompok UKM, yaitu UKM pangan, non pangan, dan kerajinan. Pengelompokan tersebut dilakukan berdasarkan perbedaan sifat dan karaktersitik dari produk yang dihasilkan oleh UKM.

Analisis ini dilakukan dengan menggunakan program RAPKMBO yang merupakan modifikasi dari RAPFISH yang dijalankan pada Microsoft Excel 2010. Berikut adalah contoh masukan dari dimensi ekonomi untuk mendapatkan nilai indeks keberlanjutan.

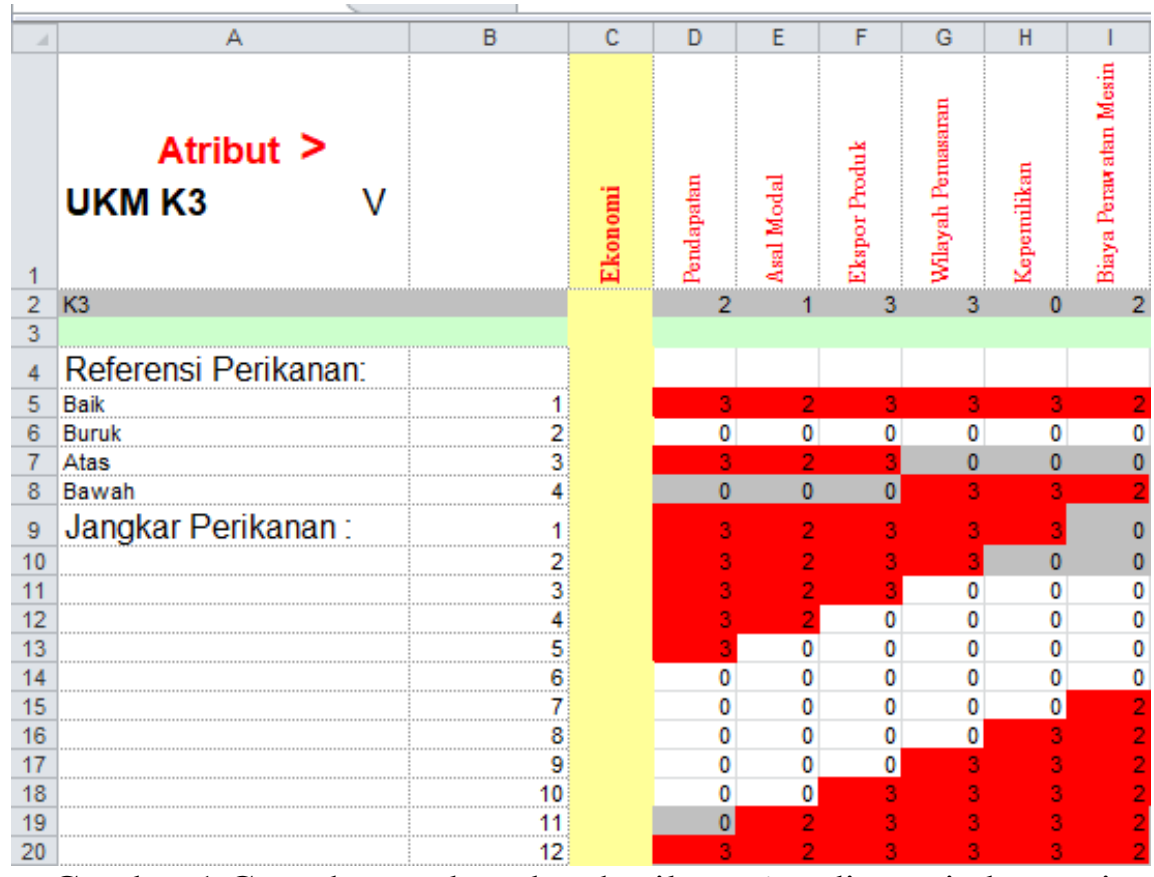

Gambar 1 Contoh masukan data hasil scoring dimensi ekonomi 
Pada Gambar 2 terlihat bahwa hasil scoring telah dimasukkan sesuai dengan format layout dari RAPFISH. Pada kolom excel, terdapat skor untuk masing-masing atribut, yang kemudian posisi data di input pada sesuai posisi data pada layout kedalam tool RAPFISH. Hasil dari proses ordinasi (penentuan jarak), rotate flip and scale terhadap jangkar ditampilkan dalam bentuk grafik.

\section{Ordinasi RAPKMBO}

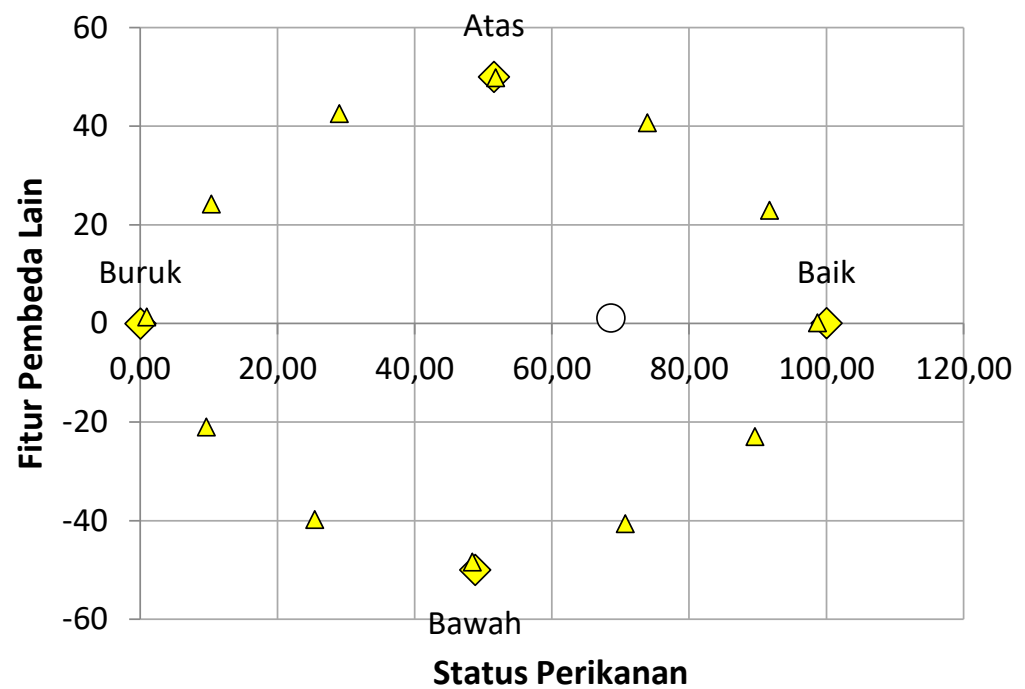

Gambar 2 Contoh Hasil Indeks Keberlanjutan dimensi ekonomi pada UKM K3

Dapat dilihat pada gambar 3, pada dimensi ekonomi UKMKM K3 memiliki nilai indeks keberlanjutan diatas $60 \%$. Jika dilihat lebih detail, maka UKM K3 memiliki nilai indeks keberlanjutan sebesar 68,52\%. Hasil indeks keberlanjutan UKM lainnya dapat dilihat pada lampiran 4. Nilai indeks keberlanjutan dikatakan semakin baik bila mendekati good fit (100\%) dan semakin buruk bila mendekati bad fit $(0 \%)$.
Selain nilai sustainability index, dalam menilai validasi terdapat nilai stress dan R2 yang digunakan dalam validasi nilai. Validasi nilai ini berfungsi untuk mengetahui diperlukan atau tidaknya penambahan atribut dan mencerminkan keakuratan dimensi yang dikaji dengan keadaan sebenarnya (Hidayanto et al 2009). Nilai stress dan R2 UKM di Kota Bogor dapar dilihat pada tebel 3.

Tabel 3 Nilai Indeks Keberlanjutan Rata-Rata UKM Kota Bogor

\begin{tabular}{ccccccc}
\hline \multirow{2}{*}{ Dimensi } & $\begin{array}{c}\text { UKM } \\
\text { Pangan }\end{array}$ & $\begin{array}{c}\text { UKM Non } \\
\text { Pangan }\end{array}$ & $\begin{array}{c}\text { UKM } \\
\text { Kerajinan }\end{array}$ & $\bar{X}$ & Stress & \multirow{2}{*}{$\mathrm{R}^{2}$} \\
\cline { 2 - 4 } & \multicolumn{3}{c}{ Nilai Indeks (\%) } & & & \\
\hline Ekologi & 44,68 & 41,99 & 37,91 & 41,53 & 0,17 & 0,92 \\
Sosial & 74,17 & 62,39 & 70,37 & 68,98 & 0,16 & 0,93 \\
Ekonomi & 29,60 & 44,95 & 42,04 & 38,86 & 0,15 & 0,94 \\
$\bar{X}$ & $\mathbf{4 9 , 4 8}$ & $\mathbf{4 9 , 7 7}$ & $\mathbf{5 0 , 1 1}$ & $\mathbf{4 9 , 8}$ & & \\
\hline Kategori & Cukup & Cukup & Baik & Cukup & & \\
\hline
\end{tabular}


Pada tabel 3, dapat dilihat setiap dimensi memiliki nilai stress kurang dari 0,25 dan nilai R2 lebih tinggi dari 0,80 atau mendekati 1. Berdasarkan hasil tersebut, menunjukan hasil analisis akurat untuk menggambarkan kondisi UKM kota Bogor dan tidak perlu adanya penambahan atau pengurangan atribut yang digunakan. Menurut Fauzi dan Anna (2002) nilai stress dibawah 0,25 menunjukan bahwa data yang dihasilkan telah good of fit, yang berarti data dapat mencerminkan kondisi yang sesungguhnnya. Sedangkan nilai R2 diatas 0,9 mengindikasikan bahwa model yang digunakan, sudah menjelaskan $90 \%$ dari model yang ada pada keadaan sebenarnya (Hidayanto et al 2009).

Berdasarkan hasil pengukuran indeks keberlanjutan (sustainability index) pada tabel 3, ditunjukan bahwa nilai indeks ratarata UKM di kota Bogor sebesar 49.8 yang berarti tingkat keberlanjutan UKM kota Bogor berada pada kondisi cukup (nilai indeks dibawah 50). Hasil tersebut merupakan nilai rata-rata dari ketiga kategori UKM yakni pangan, non pangan, dan kerajinan dengan nilai indeks masing-masing sebesar 49.48, 50.11, dan 49.77. Nilai tersebut menunjukan bahwa tingkat keberlanjutan UKM kerajinan masuk dalam kategori baik (nilai indeks $50<\mathrm{x} \leq 75$ ), sedangkan UKM pangan dan non pangan masuk dalam kategori cukup. Meskipun nilai indeks keberlanjutan UKM kerajinan leih tinggi, namun hasil ini tidak berbeda secara signifikan atau dapat dikatakan nilai indeks keberlanjutan ketiga kategori relatif sama. Untuk meningkatkan indeks kinerja UKM kota Bogor evaluasi kinerja perlu dilakukan terhadap dimensi yang belum maksimal yang paling mempengaruhi kinerjanya yakni dimensi ekologi dan ekonomi. Hal ini bertujuan agar status keberlanjutan UKM di Kota Bogor dapat ditingkatkan.

\section{Analisis Monte Carlo, Analisis Leverage, dan strategi peningkatan kinerja UKM di Kota Bogor}

Hasil analisis Monte Carlo merupakan perbandingan indeks kesalahan acak yang dibandingkan dengan nilai indeks keberlanjutan. Analisis ini berfungsi sebagai validasi atribut untuk memastikan besarnya error dari nilai indeks keberlanjutan. Analisis dilakukan pada dua UKM pangan dengan nilai indeks paling rendah yakni UKM P1 dan paling tinggi yakni UKM P8 untuk melihat perbedaan strategi perbaikan kinerja pada kedua UKM tersebut. Selisih nilai indeks keberlanjutan dengan Monte Carlo UKM P1 digambarkan pada tabel 8 .

Tabel 4 Analisis Monte Carlo UKM P1

\begin{tabular}{clccc}
\hline Dimensi & $\begin{array}{c}\text { Nilai Indeks } \\
(\%)\end{array}$ & $\begin{array}{c}\text { Monte } \\
\text { Carlo } \\
(\mathrm{a})\end{array}$ & $\begin{array}{c}\text { Selisih } \\
(\%)\end{array}$ \\
& & 16,07 & 17,65 & 1,58 \\
\hline 1. & Ekologi & 45,79 & 45,41 & 0,38 \\
2. Sosial & 21,09 & 21,96 & 0,87 \\
3. & Ekonmi & & \\
\hline
\end{tabular}

Pada tabel 4, dapat dilihat bahwa untuk UKM P1 memiliki selisih nilai Monte Carlo yang kurang dari 5\%. Dapat diketahui bahwa selisih terbesar dari ketiga dimensi adalah pada dimensi ekologi sebesar 1,58\%. Kecilnya selisih yang kurang dari $5 \%$ menunjukan hasil yang valid dengan nilai random error yang kecil (Nurmalina 2008). Hasil ini menunjukan bahwa simulasi yang dilakukan menggunakan analisis Monte Carlo dapat menggambarkan keadaan UMKM yang sebenarnya karena memiliki 
tingkat kepercayaan yang tinggi dengan error yang rendah (Kavanagh dan Pitcher 2004). Hasil tersebut disebabkan oleh ragam pemberian skor akibat perbedaan opini yang kecil, kesalahan pembuatan skor kecil, proses analisis berulang yang stabil, dan kesalahan pemasukan data serta data yang hilang dapat dihindari (et al. 2015). Hasil ini menunjukkan bahwa nilai random error terbesar diantara ketiga dimensi memiliki nilai dibawah 5\% sehingga hasil ini valid dan menggambarkan kondisi UKM yang sebenarnya. Representasi nilai indeks keberlanjutan dari hasil olah data UKM P1 digambarkan dalam diagram layang untuk memudahkan pemetaan kondisi faktual UKM. Representasi tersebut diperlihatkan pada Gambar 4.

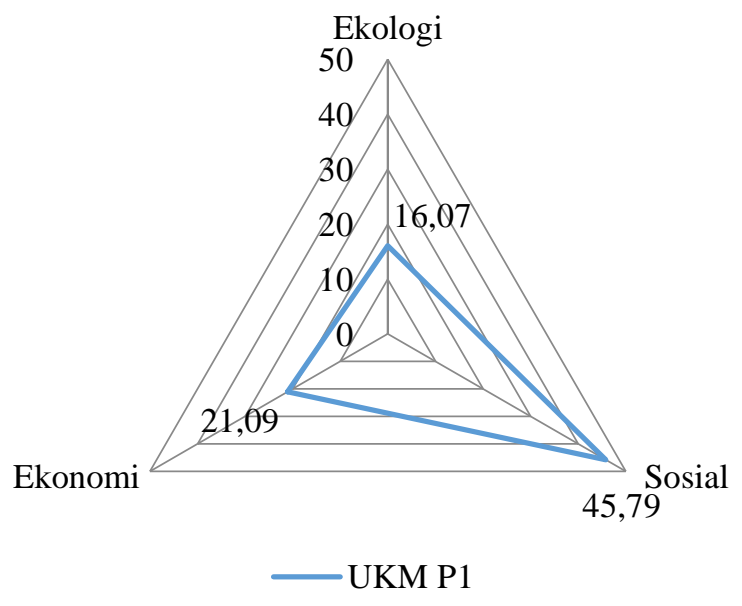

Gambar 3 Diagram Layang Indeks keberlanjutan UKM P1

Dari gambar 4 terlihat bahwa nilai indeks keberlanjutan dari UKM P1 berada pada rentang 16,07\%-45,79 \%. Dimensi Ekologi dan ekonomi mendapatkan nilai indeks rendah dan termasuk pada kategori kinerja yang buruk, sedangkan dimensi sosial masuk pada kategori cukup. Dari gambar diatas dimensi ekologi memiliki nilai teredah sebesar 16,07\%. Dimensi ekologi sebagai dimensi dengan nilai indeks terendah, kemudian dianalisis dengan analisis Leverage untuk mengetahui atribut paling sensitif yang mempengaruhi rendahnya nilai indeks keberlanjutan UKM P1. Hasil analisis Leverage dimensi ekologi UKM P1 dapat dilihat pada gambar 5 .

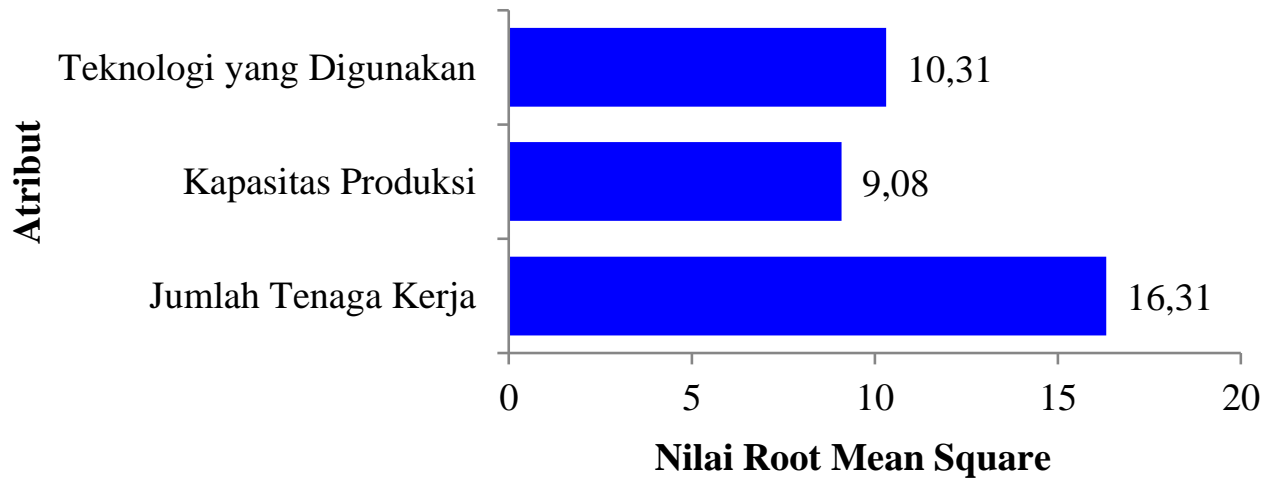

Gambar 4 Hasil Analisis Leverage Dimensi Ekologi UKM P1 
Berdasarkan hasil analisis Leverage pada dimensi Ekologi UKM P1 dapat dilihat pada gambar 5 bahwa atribut paling sensitif adalah jumlah tenaga kerja. Hal ini diketahui dengan melihat nilai RMS (Roor Mean Square) pada jumlah tenaga kerja dengan nilai RMS 16,31. Nilai RMS yang tinggi menunjukkan bahwa atribut tersebut semakin sensitif peranannya dalam peningkatan sustainability index (Hidayanto et al. 2009). Hasil analisis Leverage ini kemudian digunakan sebagai acuan strategi peningkatan kinerja, yang dilakukan dengan simulasi. Hasil simulasi perbaikan kinerja UKM P1 dapat dilihat pada tabel berikut.

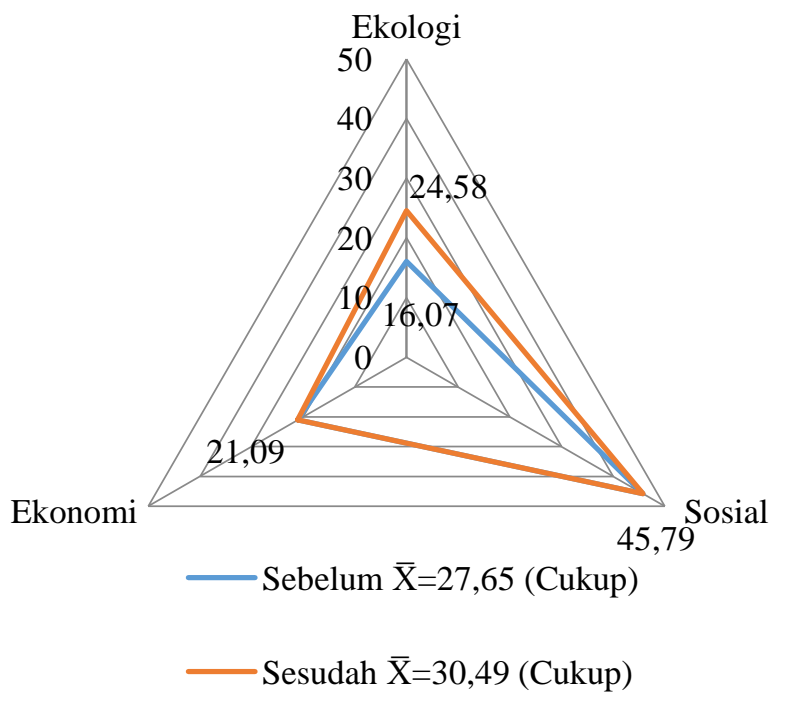

Gambar 5 Hasil Simulasi Perbaikan Kinerja UKM P1

Berdasarkan simulasi pada gambar 6 , dimensi ekologi pada UKM P1 meningkat dari semula $16,07 \%$ menjadi $24,58 \%$ atau terjadi peningkatan sebesar $8,51 \%$ pada dimensi ekologi. Hal ini menyebabkan meningkatnnya indeks keberlanjutan ratarata UKM P1 yang semula $27,65 \%$ menjadi $30,49 \%$ atau meningkat sebesar $2,84 \%$. Hal ini dilakukan dengan meningkatkan nilai atribut jumlah tenaga kerja, dengan kata lain UKM P1 perlu menambah jumlah tenaga kerjanya sebanyak 2 orang sehingga memenuhi indikator 6-10 tenaga kerja. Hasil ini belum signifikan karena nilai indeks keberlanjutan UKM P1 masih tergolong kategori cukup atau tidak terjadi perubahan status keberlanjutan dari hasil perbaikan yang dilakukan. Maka perlu dilakukan perbaikan lainya baik perbaikan pada penambahan tenaga kerja kembali ataupun pada atribut lain sehingga meningkatkan nilai indeks keberlanjutanya.

Analisis juga dilakukan pada UKM P8 dengan nilai ideks tertinggi pada UKM pangan. Selisih nilai indeks keberlanjutan dengan Monte Carlo UKM P8 digambarkan pada tabel 5 .

Hasil pada tabel 5 juga menunjukan bahwa data telah valid dengan nilai selisih kurang dari $5 \%$. Selisih terbesar pada UKM P8 adalah sebesar 4,07\% pada dimensi sosial. Hasil ini menunjukkan bahwa nilai random error terbesar diantara ketiga dimensi sebesar $4,07 \%$, dan nilai tersebut kurang dari 5\% sehingga hasil ini valid dan dapat menggambarkan kondisi UKM yang sebenarnnya. Representasi nilai indeks keberlanjutan dari hasil olah data UKM P8 digambarkan dalam diagram layang untuk memudahkan pemetaan kondisi faktual 
UKM. Representasi tersebut diperlihatkan pada Gambar 7.

Tabel 5 Analisis Monte Carlo UKM P8

\begin{tabular}{llccc}
\hline Dimensi & $\begin{array}{c}\text { Nilai Indeks } \\
(\%)\end{array}$ & $\begin{array}{c}\text { Monte } \\
\text { Carlo } \\
(\mathrm{a})\end{array}$ & $\begin{array}{c}\text { Selisih } \\
(\%) \\
(\mathrm{a}-\mathrm{b})\end{array}$ \\
\hline 1. Ekologi & 84,03 & 81,82 & 2,21 \\
2. Sosial & 100 & 95,93 & 4,07 \\
3. & Ekonmi & 40,17 & 40,46 & 0,29 \\
\hline
\end{tabular}

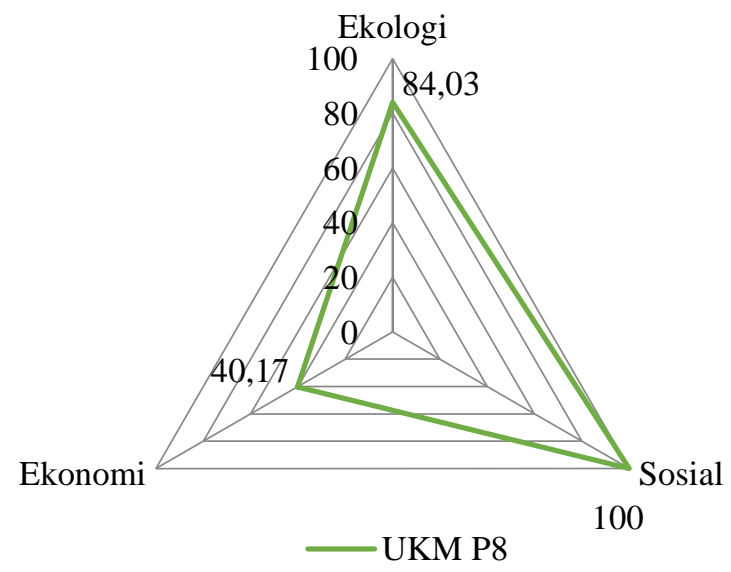

Gambar 6 Diagram Layang Indeks keberlanjutan UKM P8

Dari gambar 7 terlihat bahwa nilai indeks keberlanjutan dari kedua UKM P8 berada pada rentang 40,17\%-100\%. Pada UKM P8 tidak terdapat dimensi dengan kategori buruk, dimensi terendah adalah dimensi ekonomi dengan nilai indeks $40,17 \%$, masuk kategori cukup, sedangkan dimensi ekologi dan sosial masuk dalam kategori sangat baik. Dimensi ekonomi pada UKM P8 kemudian dilakukan analisis Leverage untuk mengetahui strategi yang dapat dilakukan untuk meningkatkan kinerjannya. Hasil analisis Leverage dimensi ekonomi UKM P8 dapat dilihat pada gambar 8 .

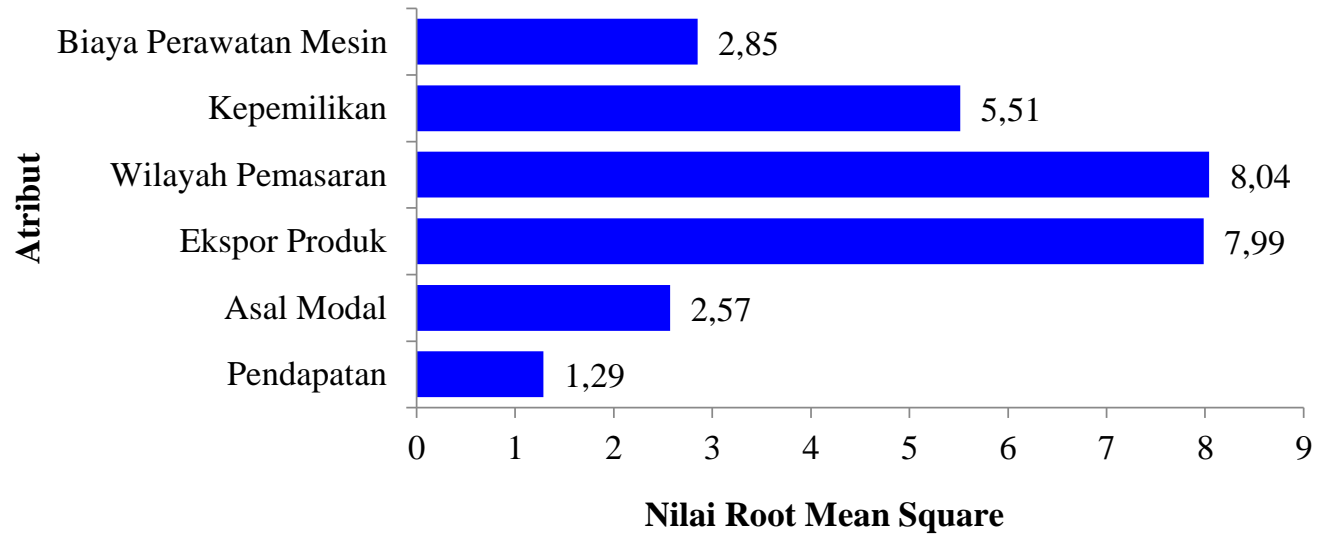

Gambar 7 Hasil Analisis Leverage UKM P8 
Berdasarkan hasil analisis Leverage pada dimensi Ekonomi UKM P8 dapat dilihat pada gambar 8 bahwa atribut paling sensitif adalah wilayah pemasaran. Hal ini diketahui dengan melihat nilai RMS (Roor Mean Square) tertinggi pada jumlah tenaga kerja dengan nilai RMS 8,04. Hasil analisis Leverage ini kemudian digunakan sebagai acuan strategi peningkatan kinerja. Hasil perbaikan kinerja UKM P8 dapat dilihat pada tabel berikut.

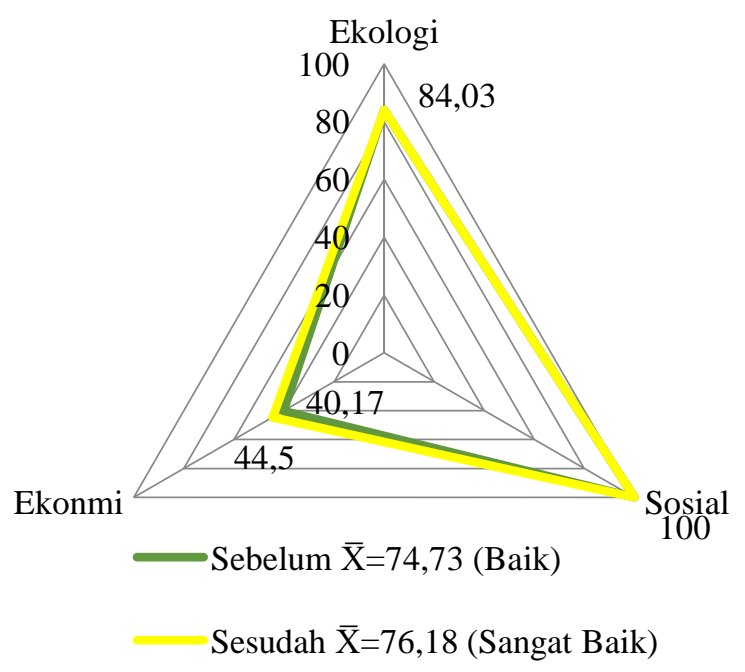

\section{Gambar 8 Hasil Simulasi Perbaikan Kinerja UKM P8}

Berdasarkan hasil perbaikan, dimensi ekonomi UKM P8 meningkat sebesar 4,33\% dari semula 40,17\% menjadi 44,50\%. Hal ini meningkatkan indeks keberlanjutan rata-rata UKM P8 yang semula $74,73 \%$ menjadi $76,18 \%$ atau meningkat sebesar $1,45 \%$. Hal ini dilakukan dengan meningkatkan nilai atribut wilayah pemasaran sebanyak satu tingkat, dengan kata lain UKM P8 perlu memperluas wilayah pemasaranya hingga masuk pasar ekspor. Menurut Rokhayati (2015), perluasan pasar dapat digunakan untuk mengukur keberhasilan suatu industri. Semakin luas pasar peluang keberhasilan industrinnya semakin besar. Hasil ini menyebabkan penigkatan kategori status keberlanjutan pada UKM P8 dari kategori baik (Nilai Indeks $50<\mathrm{x} \leq 75$ ) menjadi kategori sangat baik (Nilai indeks >75). Namun peningkatan masih belum signifikan dan perlu dilakukan perbaikan pada atribut lain untuk mempertahankan status sangat baik maupun daya saing pada UKM P8.
Dengan cara yang sama evaluasi kinerja juga dilakukan pada UKM non pangan dan UKM kerajinan dengan status keberlanjutan paling rendah dan paling tinggi. Evaluasi dilakukan pada UKM NP10 dengan nilai indeks keberlanjutan paling rendah dan NP1 dengan nilai indeks keberlanjutan paling tinggi pada UKM non pangan. Sedangkan pada UKM kerajinan, evaluasi dilakukan pada UKM K8 dengan nilai indeks keberlanjutan paling rendah dan $\mathrm{K} 3$ dengan nilai indeks keberlanjutan paling tinggi.

Berdasarkan hasil perbaikan kinerja pada UKM NP10, indeks keberlanjutan dimensi ekonomi menigkat sebesar 2,19\% dari semula $11,36 \%$ menjadi $13,55 \%$ dan meningkatkan indeks keberlanjutan rata-rata UKM NP10 yang semula $33,71 \%$ menjadi $34,31 \%$ atau meningkat sebesar $0,60 \%$. Hal ini dilakukan dengan meningkatkan nilai atribut asal modal sebanyak satu tingkat, dengan kata lain UKM NP10 perlu 
menambah sumber modalnya selain modal sendiri juga dari pihak lain seperti pihak Bank atau pihak pemberi modal lain. Hasil ini belum signifikan karena nilai indeks keberlanjutan UKM NP10 masih tidak terjadi perubahan status keberlanjutan dari hasil perbaikan yang masih berada pada kategori cukup. Maka perlu dilakukan perbaikan lainya baik perbaikan pada atribut lain sehingga meningkatkan nilai indeks keberlanjutanya.

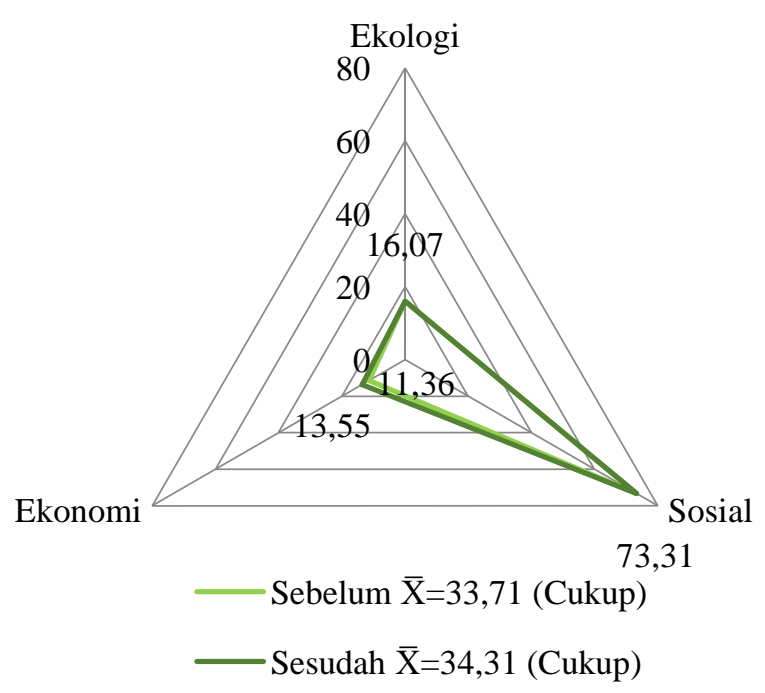

Gambar 9 Hasil Simulasi Perbaikan Kinerja UKM NP10

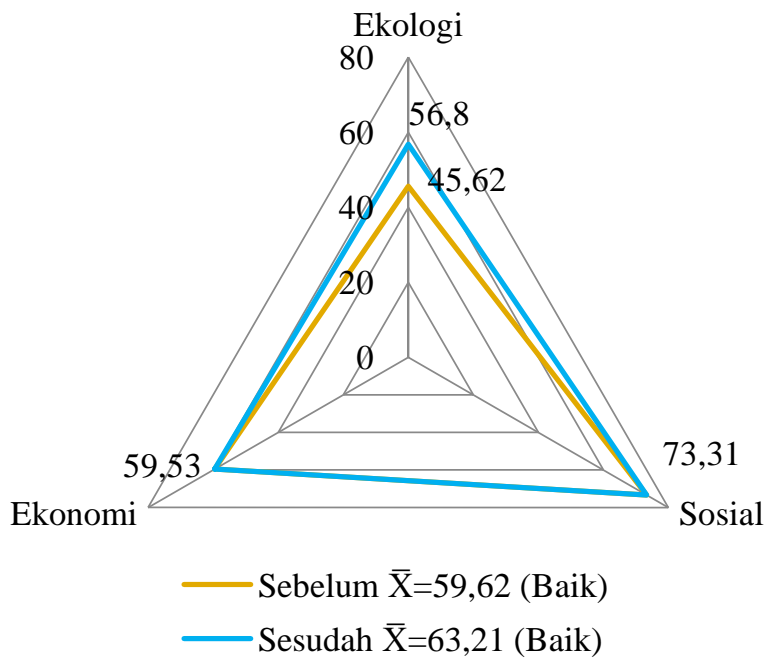

Gambar 10 Hasil Simulasi Perbaikan Kinerja UKM NP1

Berdasarkan hasil perbaikan, dimensi ekologi UKM NP1 meningkat sebesar $11.18 \%$ dari semula $45,62 \%$ menjadi $56,80 \%$ dan meningkatkan indeks keberlanjutan ratarata UKM NP1 yang semula 59,62\% menjadi
$63,21 \%$ atau meningkat sebesar 3,6\%. Hal ini dilakukan dengan meningkatkan nilai atribut kapasitas produksi sebanyak satu tingkat, dengan kata lain UKM NP1 perlu meningkatkan kapasitas produksinya 
sehingga kapasitasnya lebih tinggi. Hasil perbaikan nilai atribut kapasitas produksi sebanyak satu tingkat cukup memberikan pengaruh yang cukup signifikan pada peningkatan status keberlanjutan dimensi ekologi UKM NP1 yang semula kategori cukup naik sebesar $11,18 \%$ sehingga kategorinya baik. Namun peningkatan kinerja masih perlu dilakukan pada atribut lain untuk meningkatkan status kebelanjutan UKM NP1 sehingga menjadi sangat baik yang menjadikan daya saingnya semakin besar.

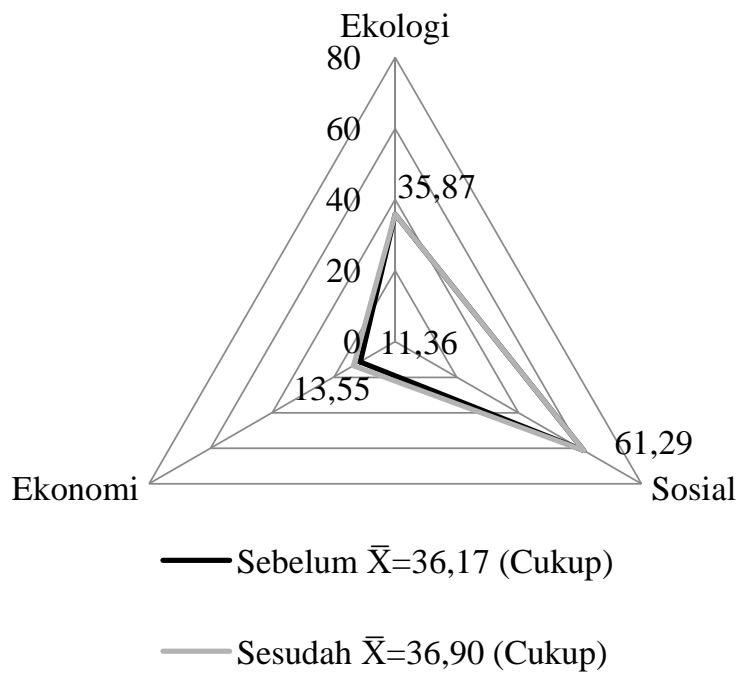

Gambar 11 Hasil Simulasi Perbaikan Kinerja UKM K8

Berdasarkan hasil perbaikan kinerja pada tabel 14, dimensi ekonomi pada UKM K8 menigkat sebesar 2,19\% dari semula $11,36 \%$ menjadi $13,55 \%$ dan meningkatkan indeks keberlanjutan rata-rata UKM K8 yang semula $36,17 \%$ menjadi $36,90 \%$ atau meningkat sebesar $0,73 \%$. Hal ini dilakukan dengan meningkatkan nilai atribut asal modal sebanyak satu tingkat, dengan kata lain UKM NP10 perlu menambah sumber modalnya selain modal sendiri juga dari pihak lain seperti pihak Bank atau yang lain. Hasil ini belum signifikan karena nilai indeks keberlanjutan UKM NP10 masih tidak terjadi perubahan status keberlanjutan dari hasil perbaikan yang masih berada pada kategori cukup. Maka perlu dilakukan perbaikan atribut lain sehingga meningkatkan nilai indeks keberlanjutanya.

Berdasarkan hasil perbaikan, dimensi ekologi UKM K3 meningkat sebesar 0,57\% dari semula $68,52 \%$ menjadi $69,09 \%$ dan meningkatkan indeks keberlanjutan rata-rata
UKM K3 yang semula $71,07 \%$ menjadi $71,26 \%$ atau meningkat sebesar $0,19 \%$. Hal ini dilakukan dengan meningkatkan nilai atribut kepemilikan sebanyak satu tingkat, dengan kata lain UKM K3 perlu status hukum kepemilikanya hingga memiliki sebuah badan hukum yang lebih baik. Hasil perbaikan nilai atribut kepemilikan belum memberikan peningkatan signifikan karena hanya terjadi sedikit peningkatan hasil simulasi perbaikan. Maka perlu dilakukan perbaikn pada atribut lain sehingga meningkatkan nilai indeks keberlanjutanya.

Dari hasil evaluasi kinerja yang dilakukan terhadap ketiga kategori UKM kota Bogor, maka dapat diketahui bagi setiap UKM memiliki strategi dan peningkatan nilai indeks keberlanjutan yang berbeda-beda. Pada UKM pangan perbaikan lebih berfokus pada dimensi ekologi dan ekonomi dengan strategi peningkatan jumlah tenaga kerja dan wilayah pemasaran yang masih sebatas sekitar wilayah Bogor. Begitupun pada UKM 
non pangan perbaikan juga berfokus pada perbaikan dimensi ekolgi dan ekonomi hanya saja strategi yang berbeda perlu dilakukan dengan perluasan sumber modal dan peningkatan kapasitas poduksi. Sedangkan pada UKM kerajinan perbaikan berfokus pada dimensi ekonomi dengan strategi peningkatan kinerja pada perluasan sumber modal dan status hukum kepemilikan.

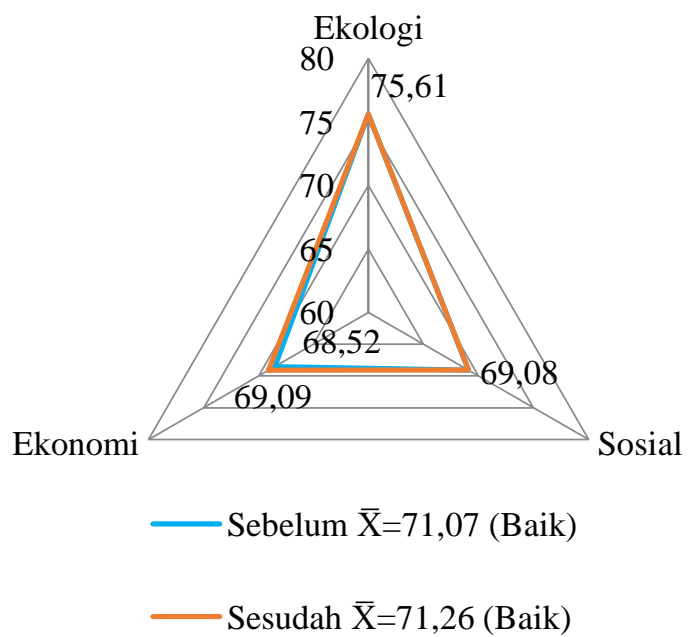

Gambar 12 Hasil Simulasi Perbaikan Kinerja UKM K3

Pada UKM P8 dengan status keberlanjutan tertinggi pada kategori pangan, hasil simulasi memperlihatkan bahwa indeks kinerja rata-rata UKM P8 dapat memenuhi kategori sangat baik (nilai indeks $>75$ ) yang semula kategori baik (nilia indeks $50<\mathrm{x} \leq 75$ ). Hal ini menandakan bahwa dengan strategi peningkatan kinerja yang tepat dan efektif dapat meningkatakan status keberlanjutan UKM di kota Bogor. Dimensi ekologi dan ekonomi menjadi dimensi yang perlu mendapat perhatian dalam peningkatan daya saing UKM kota Bogor. Hal ini dikarenakan hampir keseluruhan dari UKM di kota Bogor memiliki masalah dengan dimensi tersebut. Hal ini deitandai dengan dimensi ekologi dan ekonomi menjadi mayoritas sebagai dua dimensi terendah. Simulasi kemudian dilakukan dengan memaksimalkan atribut paling sensitif pada dimensi yang perlu mendapat perhatian, yakni pada dua dimensi terendah masing-masing UKM. Berikut merupakan hasil evaluasi kinerja UKM kota Bogor dengan perbaikan pada dimensi terkait.

Tabel 6 Nilai Indeks Keberlanjutan Rata-Rata UKM Kota Bogor Hasil Evaluasi Kinerja

\begin{tabular}{ccccccc}
\hline \multirow{2}{*}{ Dimensi } & \multicolumn{5}{c}{ Indeks Keberlanjutan UKM (\%) } \\
\cline { 2 - 7 } & \multicolumn{2}{c}{ Pangan } & \multicolumn{2}{c}{ Non Pangan } & \multicolumn{2}{c}{ Kerajinan } \\
\cline { 2 - 7 } & Sebelum & Sesudah & Sebelum & Sesudah & Sebelum & Sesudah \\
\hline Ekologi & 44,68 & 60,31 & 41,99 & 58,16 & 37,91 & 62,19 \\
Sosial & 74,17 & 75,76 & 62,39 & 65,67 & 70,37 & 72,51 \\
Ekonomi & 29,60 & 40,12 & 44,95 & 54,55 & 42,04 & 51,37 \\
$\bar{X}$ & $\mathbf{4 9 , 4 8}$ & $\mathbf{5 8 , 7 3}$ & $\mathbf{4 9 , 7 7}$ & $\mathbf{5 9 , 4 6}$ & $\mathbf{5 0 , 1 1}$ & $\mathbf{6 2 , 0 2}$ \\
\hline Kategori & Cukup & Baik & Cukup & Baik & Baik & Baik \\
\hline
\end{tabular}


Pada tabel 6, dengan evaluasi kinerja yang dilakukan berdasarkan rekomendasi analisis Leverage pada dimensi dengan nilai indeks kurang baik. Terjadi peningkatan nilai indeks keberlanjutan pada UKM pangan yang semula $49,48 \%$ menjadi $58,73 \%$ atau meningkat $9,25 \%$. Pada UKM non pangan nilai indeks meningkat dari semula $49,77 \%$ menjadi $59,46 \%$ atau meningkat $9,69 \%$. Pada UKM kerajinan nilai indeks meningkat dari semula $50,11 \%$ menjadi $62,02 \%$ atau meningkat sebesar $11,92 \%$. Hal ini menyebabkan meningkatnya status keberlanjutan pada UKM pangan dan non pangan dari cukup menjadi kategori baik. Perubahan indeks keberlanjutan untuk ketiga UKM lebih jelas jika digambarkan secara visual menggunakan diagram layang. Berikut adalah diagram layang perubahan indeks keberlanjutan untuk UKM di Kota Bogor.

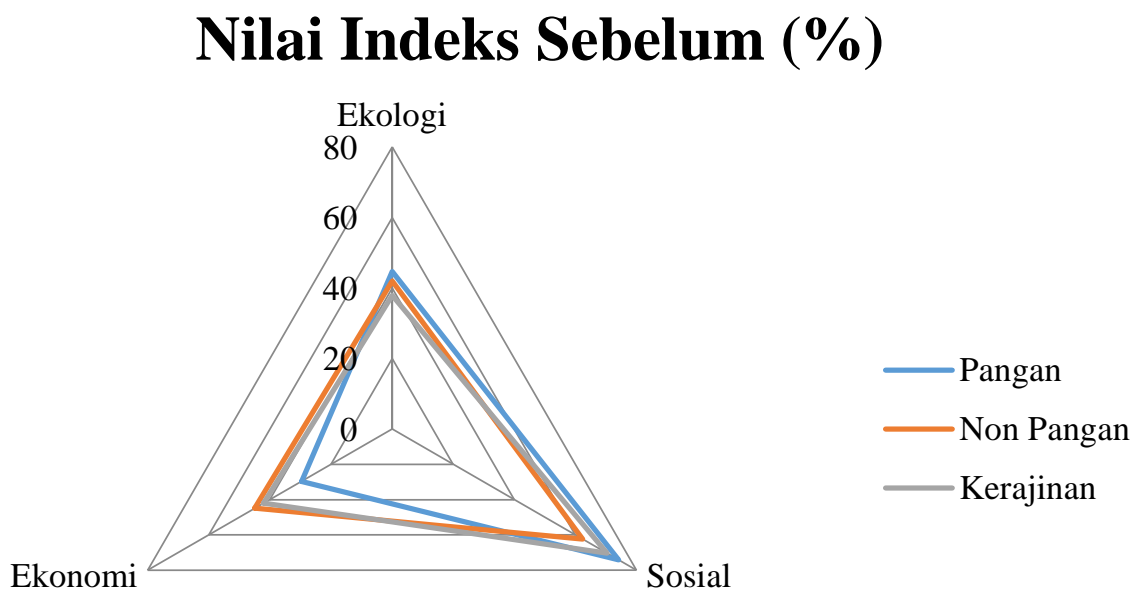

\section{Nilai Indeks Sesudah (\%)}

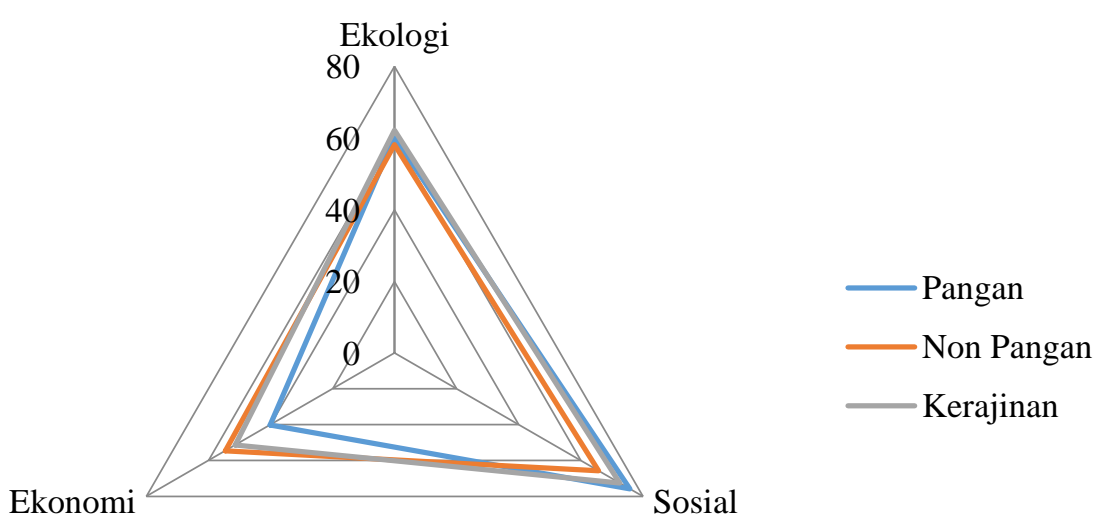

Gambar 13 Diagram layang indeks keberlanjutan UKM di Kota Bogor sebelum dan sesudah perbaikan 
Gambar 14 menerangkan tentang perbedaan indeks keberlanjutan UKM Kota Bogor sebelum dan setelah evaluasi peningkatan kinerja. Dapat dilihat pada gambar bahwa terjadi peningkatan yang cukup signifikan. Perbaikan ini meningkatkan status keberlanjutan UKM kota Bogor secara keseluruhan sehingga masuk kategori baik, dengan nilai indeks rata-rata sebesar $60,07 \%$, atau meningkat sebanyak 10,27\% dari semula 49,8\%. Hasil ini menunjukan, bahwa dengan memaksimalkan perbaikan di atribut paling sensiif pada dimensi yang kurang baik (nilai indeks rendah) dapat meningkatkan status keberlanjutan yang cukup signifikan. Peningkatan ini menunjukan bahwa bahwa UKM kota Bogor seharusnya mampu mencapai kinerja dengan kategori baik berdasarkan simulasi perbaikan kinerja jika melakukan perbaikan hasil analisi Leverage. Maka untuk mencapai hal tersebut, perbaikan pada dimensi ekologi dan ekonomi merupakan hal utama yang perlu diperhatikan. Hal ini juga membuktikan bahwa pengukuran sustainability index dengan multidimentional scaling dapat dijadikan sebagai alat untuk menentukan pengambilan keputusan dalam strategi peningkatan daya saing UKM di kota Bogor.

\section{SIMPULAN DAN SARAN}

\section{Kesimpulan}

Hasil pegukuran indeks keberlanjutan dengan modifikasi RAPFISH menunjukan bahwa nilai indeks keberlanjutan rata-rata UKM kota Bogor masuk dalam kategori cukup berkembang dengan nilai 49,8\%. Hasil tersebut meupakan hasil rata-rata dari ketiga kategori UKM yang ada di kota Bogor yakni UKM pangan, non pangan, dan kerajinan, dengan nilai indeks keberlanutan masingmasing sebesar 49,48\%, 49,77\%, dan $50,11 \%$. Hasil ini menunjukan bahwa kinerja UKM kerajinan di kota Bogor lebih baik dibandingkan dengan UKM pangan dan non pangan. Hasil simulasi perbaikan kinerja pada ketiga kategoi UKM menunjukan bahwa setiap UKM memiliki strategi yang berbeda untuk meningkatkan daya saingnya. Perbaikan kinerja perlu dilakukan untuk peningkatan daya saing yang ditandai dengan meningkatnya nilai indeks keberlanjutan maupun status keberlanjutanya. Dimensi ekologi dan ekonomi merupakan dimensi yang perlu mendapatkan perhatian dalam peningkatan daya saing UKM. Hasil simulasi perbaikan kinerja pada dimensi ekologi dan ekonomi meningkatkan nilai indeks keberlanjutan rata-rata keseluruhan UKM kota Bogor. Indeks keberlanjutan UKM pangan, non pangan, dan kerajinan meningkat masing-masing sebesar 9,25\%, $9,69 \%$, dan $11,92 \%$, dan meningkatkan status keberlanjutan UKM pangan dan non pangan sehingga masuk dalam kategori baik. Hasil perbaikan juga meningkatkan nilai indeks keberlanjutan rata-rata UKM kota Bogor sebesar $10,27 \%$ dari semula $49,8 \%$ menjadi $60,07 \%$ sehingga memperbaiki status keberlanjutan UKM kota Bogor pada kategori baik.

\section{Saran}

Penentuan dimensi, atribut, dan indikator yang digunakan masih relatif umum. Penulis merekomendasikan agar atribut dan indikator pada penelitian selanjutnya lebih spesifik dan detail agar dapat menggambarkan kondisi UKM yang diteliti secara lebih aktual. Selain itu dimensi yang digunakan perlu ditambahkan agar lebih detail dan rinci sesuai kriteria dari suatu UKM.

\section{DAFTAR PUSTAKA}

$\begin{array}{rrr}\text { Brahmasari I A, Suprayetno A. } & 2008 . \\ \text { Pengaruh } & \text { Motivasi } & \text { Kerja, } \\ \text { Kepemimpinan dan Budaya Organisasi } & \text { Organ } \\ \text { terhadap Kepuasan Kerja Karyawan }\end{array}$


serta Dampaknya pada Kinerja Perusahaan (Studi Kasus pada PT. Pei Hai International Wiratama Indonesia). Jurnal Manajemen dan Kewirausahaan. Vol 10 (2): 124-135.

Clarke KR. 1993. Non-parametric Multivariate Analysis of Changes in Community Structure. Australian Journal of Ecology. Vol (18): 117-143.

[Depkop] Departemen Koperasi. 2013. Data Usaha Mikro, Kecil, Menengah (UKM) dan Usaha Besar (UB) Tahun 20122013 [Internet]. [diunduh 19 Februari 2018] Tersedia pada:http:/ /www.depkop.go.id/beritainformasi/da ta-informasi/data-UKM/.

[DPR RI] Dewan Perwakilan Rakyat Republik Indonesia. 2008. UndangUndang Nomor 20 Tahun 2008 tentang Usaha Mikro, Kecil, dan Menengah. Jakarta (ID): DPR RI.

[EIS] English Institute of Sport. 2016. Performance Analysis [Internet]. [diunduh

01 Juli 2016] Tersedia pada:http://ww w.eis2win.com/expertise/performance analysis/.

Fauzi A, Anna S. 2002. Evaluasi Status Keberlanjutan Pembangunan Perikanan: Aplikasi Pendekatan RAPFISH (Studi Kasus Perairan Pesisir DKI Jakarta). Jurnal Pesisir dan Lautan. Vol 4 (3). ISSN: 1410-7821.

Fitanto B. 2019. Analisis Omset dan Posisi Bersaing pada Klaster Usaha Kecil Menengah (UKM) Sepatu Kota Mojokerto. Jurnal of Indonesian Applied Economics. Vol 3 (1). 23-36.

Fitrianti R S, Kamal M M, Kurnia R. 2014. Analisis Keberlanjutan Perikanan Ikan Terbang di Kabupaten Takalar, Sulawesi Selatan. Depik. Vol 3 (2). 118-127. ISSN 2089-7790.
Hartrisari et al. 2015. Data Primer Penelitian UKM Agroindustri di Kota Bogor. Bogor (ID).

Hidayanto M, Supiandi S, Yahsa S, Amien L I. 2009. Analisis Keberlanjutan Perkebunan Kakao Rakyat di Kawasan Perbatasan Pulau Sebatik, Kabupaten Nunukan, Provinsi Kalimantan Timur. Jurnal Agro Ekonomi. Vol 27 (2): 213229.

Junaidi, Amir A, Hardiani. 2014. Potensi klaster agroindustri usaha mikro kecil dan menengah di Provinsi Jambi. Jurnal Perspektif Pembiayaan dan Pembangunan Daerah. 2(1) : 9-20.

Kavanagh P, Pitcher TJ. 2004. Implementing Microsoft Excel Software for RAPFISH: A Technique for the Rapid Appraisal of Fisheries Status. Fisheries Center Research Report. Vol 12 (2).

Kompas. 2018. Pertumbuhan Ekonomi Kota Bogor Bertumpu pada UKM [Internet]. [diunduh 19 Februari 2018] Tersedia pada

https://kompas.id/baca/utama/2018/02/ 14/pertumbuhan-ekonomi-kota-bogorbertumpu-pada-UKM/

[KUKM Kota Bogor] Dinas Koperasi dan Usaha Menengah Kecil Kota Bogor. 2016. Data UKM [internet]. [diunduh 23 Februari 2018]. Tersedia dari: http://kUKM.kotabogor.go.id/dataUK M.

Nurmalina R. 2008. Analisis Indeks dan Status Keberlanjutan Sistem Ketersediaan Beras di Beberapa Wilayah Indonesia. Jurnal Agro Ekonomi. Vol 26 (1): 4749.

Pitcher TJ, Lam ME, Ainsworth C, Martindale A, Nakamura K, Perry RI, Ward T. 2013. Improvements to RAPFISH: A Rapid Evaluation Technique for Fisheries Integrating 
Ecological and Human Dimensions. Journal of Fish Biology. No 83, 869889.

Pitcher TJ, Preikshot D. 2001. RAPFISH: A Rapid Appraisal Technique to Evaluate the Sustainability Status of Fisheries. Fisheries Research 49: 255-270.

Prawirokusumo S. (2001). Ekonomi Rakyat: Konsep, Kebijakan, dan Strategi. Yogyakarta (ID) : BPPE

Radnor Z.J. \& Barnes D. 2007. Historical Analysis of Performance Measurement and Management in Operations Management. Journal of Productivity and Performance Management, 56(5/6): 384-396.

Rafinaldy N. (2004). Prospek pengembangan ekspor UKM. Jakarta (ID) : Infokop

Rifa'i B. 2013. Efektevitas Pemberdayaan Usaha Mikro Kecil dan Menengah (UKM) Krupuk Ikan dalam Program Pengembangan Labsite Pemberdayaan Masyarakat Desa Kedung Rejo Kecamatan Jabon Kabupaten Sidoarjo. Kebijakan dan Manajemen Publik. Vol 1 (1). ISSN 2302-34IX.
Rokhayati I. 2015. Pengukuran kinerja pada usaha mikro kecil dan menengah (UKM): suatu telaah pustaka. Jurnal Manajemen. 4(2): 94-98

Susilo SY. 2007. Masalah dan dinamika usaha kecil: studi empiris pedagang "klithikan" di alun-alun selatan. Jurnal Ekonomi. 12(1) : 64-77.

Suyitman, Sutjahjo SH, Herison C, Muladno. 2009. Status keberlanjutan wilayah berbasis peternakan di kabupaten situbondo untuk pengembangan kawasan agropolitan. Jurnal Agro Ekonomi. 27(2): 165-191.

Tahir A, Bengen DG, Susilo SB. 2002. Analisis Kesesuaian Lahan dan Kebijakan Pemanfaatan Ruang Kawasan Pesisir Teluk Balikpapan. 4(3): 43-55. ISSN 1410-7821.

Tambunan T. (2005). Promoting small and medium enterprises with a clustering approach: a policy experience from Indonesia. Journal of Small Business Management. 43(2) : 138-154. 